\title{
Witold WoŁodKIEWICZ
}

Uniwersytet Warszawski

\section{HENRYKA KUPISZEWSKIEGO WIZJA PRAWA RZYMSKIEGO}

W dniu 3 kwietnia 1994 r. zmarł Profesor Henryk Kupiszewski - ambasador Rzeczypospolitej Polskiej przy Stolicy Apostolskiej. W dwudziestą rocznicę śmierci odbyła się w Uniwersytecie Warszawskim Sesja Naukowa poświęcona osobie zmarłego i jego twórczości. W sesji oprócz przyjaciół i kolegów Henryka Kupiszewskiego ${ }^{1}$ uczestniczyli również liczni pracownicy polskich katedr prawa rzymskiego oraz młodzież prawnicza $z$ uniwersytetów polskich. Jest to pocieszające dla naszej dyscypliny naukowej (która była największą pasją Henryka), że mimo krytyk podejmowanych przez zwolenników studiów prawniczych, które miałyby nauczać nie prawa, lecz jedynie jego przepisów, tylu młodych widzi potrzebę kontynuowania studiów nad prawem rzymskim.

Henryk Kupiszewski urodził się w dniu 13.01.1927 r. we wsi Książnice Wielkie, położonej w pobliżu Krakowa, lecz znajdującej się na terenach dawnego Królestwa Kongresowego. Był więc niejako człowiekiem pogranicza, gdzie krzyżowały się dwa byłe zabory dziewiętnastowiecznych ziem Polski: rosyjski i austriacki. Obowiązywały w nich różne systemy prawne. Dorastał w trudnym okresie II wojny światowej i niemieckiej okupacji. Jako młody chłopak był związany z konspiracją antyhitlerowską. Nie przeszkodziło mu to jednak

\footnotetext{
1 Referaty wygłosili profesorowie (w kolejności wystąpień): Józef Méléze Modrzejewski, Luigi Labruna, Luigi Capogrossi, Laurens Winkel, Luigi Garofalo, Marek Kuryłowicz, Witold Wołodkiewicz, Janusz Sondel.
} 
ukończyć w terminie edukacji i uzyskać zaraz po zakończeniu wojny maturę w liceum w Bochni. W 1946 r. podjął studia prawnicze na Uniwersytecie Jagiellońskim (położonym w byłym zaborze austriackim). $\mathrm{Na}$ uniwersytecie tym prawo rzymskie wykładał prof. Wacław Osuchowski (1906-1988), wychowanek Lwowskiej Szkoły Prawa Rzymskiego, który po II wojnie światowej objął Katedrę Prawa Rzymskiego w Uniwersytecie Jagiellońskim² ${ }^{2}$.

Henryk Kupiszewski tak opisuje swoje pierwsze spotkanie z prawem rzymskim i osobą swego pierwszego Mistrza: „Profesorowi Wacławowi Osuchowskiemu zawdzięczam pierwsze zetknięcie się $\mathrm{z}$ historią i instytucjami prawa rzymskiego, Jego cotygodniowe czterogodzinne wykłady w auli przy ul. Św. Anny w Krakowie były dla nas, pierwszoroczniaków Anno Domini 1946/47, wejściem w wielki świat myśli prawniczej, były ukazaniem możliwości budowy lepszego jutra na pogorzelisku II wojny światowej. Po odbyciu seminarium historycznoprawnego moje z Nim kontakty nie były częste, ale zawsze dla mnie naukowo bardzo pożyteczne"3.

Prawo rzymskie w wydaniu Wacława Osuchowskiego - który miał dorobek w zakresie prawa rzymskiego klasycznego i bizantyjskiego - stanowiło przedmiot nie tylko historyczny, ale przede wszystkim wprowadzający do konstrukcji współczesnego prawa prywatnego. Jego wykłady, a następnie kolejne wydania podręcznika, przedstawiały prawo rzymskie w ujęciu typowo pandektystycznym, nawiązującym do układu współczesnych kodeksów cywilnych.

Dla młodego człowieka, który rozpoczynał studia prawnicze i pragnął poznać prawo, taki obraz prawa rzymskiego jako zamkniętego systemu, będącego podstawą współczesnego prawa i jego nauki, mógł być fascynujący. Henryk Kupiszewski w nekrologu Wacława Osuchowskiego tak opisuje wartości, które wpoiły mu wykłady Profesora:

2 O Wacławie Osuchowskim por. H. KuPISZEwsKi, Wacław Osuchowski (1906-1988), «Iura» 39/1988, s. 262-265; IdEM, Wacław Osuchowski 1906-1988, «Prawo Kanoniczne» 33.3-4/1990, s. 201-204; R. Wiaderna-KuŚnIERZ, Droga Wacława Osuchowskiego do profesury - w 100-lecie urodzin (1906-1988), «Studia Iuridica Lublinensia» 8/2006, s.167-176.

3 H. Kupiszewski, Prawo rzymskie a wspótczesność, Warszawa 1988, s. 7. 
„Najważniejszym nauczaniem, które pozostawił nam prof. Wacław Osuchowski, i które powinniśmy mieć na względzie w przyszłości, jest system prawa opartego na słuszności"4.

Po krótkiej praktyce (najpierw w Sądzie Grodzkim w Krakowie, a następnie w Warszawie w Ministerstwie Szkolnictwa Wyższego) Henryk Kupiszewski w 1951r. znalazł się w Instytucie Papirologii i Praw Antycznych Uniwersytetu Warszawskiego, kierowanym przez hołubionego przez ówczesną władzę prof. Rafała Taubenschlaga (1881-1952). Rafał Taubenschlag w okresie międzywojennym był profesorem prawa rzymskiego na Uniwersytecie Jagiellońskim, bardzo wysoko ocenianym przez jego poprzednika i mentora prof. Stanisława Wróblewskiego 5 .

Rafał Taubenschlag poza swymi zainteresowaniami prawem rzymskim - w okresie krakowskim - pisał również o prawie antycznym i papirologii prawniczej. W swym powojennym stosunku do badań naukowych Rafał Taubenschlag uważał, że studia papirologiczne nad prawem antycznym stanowią jedyny istotny przedmiot badań nad historią prawa. Nie widział natomiast szans na rozwój badań naukowych nad właściwym prawem rzymskim ${ }^{6}$.

4 H. Kupiszewski, Wacław Osuchowski (1906-1988)..., s. 265: È questo uno dei piú importanti insegnamenti che il prof. Wactaw Osuchowski ci ha lasciato e che dovremmo avere anche in futuro nella ricerca, di un sistema di diritto fondato sull'equità.

5 O osobie R. Taubenschlaga, por. m. in.: H. KuPISZEwsKi, Rafat Taubenschlag - Storico del diritto, «BIDR» 88/1985, s. 103-157; IDEM, Rafat Taubenschlag 188118-958, [w:] W kręgu wielkich humanistów. Kultura antyczna w Uniwersytecie Warszawskim po I wojnie światowej, pod red. I. BiEżuńskieJ-MaŁowist, Warszawa 1991, s. 21-37; W. WoŁodkIEwICZ, Rafat Taubenschlag (1881-1958) - Pierwszy przewodniczący Kolegium Arbitrów przy Polskiej Izbie Handlu Zagranicznego, [w:] Księga pamiątkowa 60-lecia Sądu Arbitrażowego przy Krajowej Izbie Gospodarczej w Warszawie, Warszawa, 1910, s.13-20; IDEM, Rafat Taubenschlag and Roman Law in Poland during Real Socialism, [w:] Classics and Communism. Greek and Latin behind the Iron Curtain, Ljubljana-Budapest-Warsaw 2013, s. 238-256. Bibliografia dzieł R. Taubenschlaga: J. Modrzejewski, [w:] Symbolae R. Taubensclag dedicatae, I, Warszawa 1956, s. 1-16.

6 Por. W. WoŁodkiewicz, Rafat Taubenschlag and Roman Law..., s. 251. 
Po pobycie w okresie II wojny światowej w Stanach Zjednoczonych Ameryki Północnej, gdzie stworzył światowy ośrodek studiów papirologicznych i prawa antycznego ${ }^{7}$, Rafał Taubenschlag powrócił w 1947 r. do Polski, gdzie otrzymał w Uniwersytecie Warszawskim Katedrę Papirologii i Praw Antycznych na Wydziale Prawa, przekształconą następnie w 1950 r. w Instytut Papirologii i Prawa Antycznego na Wydziale Historycznym. W Instytucie tym pracowali Jerzy Manteuffel, Anna Świderkówna, Józef Modrzejewski-Mélèze, Cezary Kunderewicz. Do tego zespołu dołączył Henryk Kupiszewski.

Badania Henryka Kupiszewskiego w tym okresie jego życia naukowego skupiały się (zgodnie z zainteresowaniami Mistrza) na papirologii prawniczej. Również Jego praca kandydacka, będąca w tym okresie odpowiednikiem pracy doktorskiej (obroniona w 1957 r.), dotycząca Jurydyka Aleksandryjskiego, była pracą typowo papirologiczną ${ }^{8}$.

Następnym etapem rozwoju naukowego Henryka Kupiszewskiego było uzyskanie w 1958/1959 r. - dzięki Rafałowi Taubenshlagowi stypendium Fundacji Forda ${ }^{9}$. Wykorzystał je w Münster w ośrodku kierowanym przez prof. Maxa Kasera, u którego odbywali studia (kolejno w Münster, Hamburgu i w Salzburgu) późniejsi najwybitniejsi europejscy profesorowie prawa rzymskiego. Wymienię tu - obecnego dziś Luigi Labrunę, doktora honoris causa Uniwersytetu Warszawskiego - nie mówiąc o licznych kolegach i przyjaciołach z Włoch i z innych krajów Europy ${ }^{10}$.

Max Kaser, wybitny romanista niemiecki, pozostawił niezatarty ślad na zainteresowaniach naukowych Henryka Kupiszewskiego. Zarówno tematyka rozprawy habilitacyjnej, jak i późniejsze Jego prace

7 Po powrocie do Polski kontynuował wydawanie założonego w Nowym Jorku «Journal of Juristic Papyrology».

8 Por. M. ZabŁocka, Wykaz publikacji profesora dra hab. Henryka Kupiszewskiego, «Prawo Kanoniczne» 37.3-4/1994, s. 7-20.

9 J. Modrzejewski-Mélèze uzyskał również w tym czasie stypendium Ford Foundation i zrobił naukową karierę w Paryżu.

10 Włosi: Ferdinando Bona, Ignazio Buti, Luigi Labruna, Giovanni Nicosia, Tullio Spagnolo Vigorita. Z innych krajów: Hans Peter Benöhr, Rolf Knütel, Hans Hermann Seiler, Andreas Wacke, Felix Wubbe (zmarły przed kilku dniami). 
pozostawały pod wyraźnym wpływem zainteresowań naukowych Maxa Kasera.

Wydawcy przedruku książki Henryka Kupiszewskiego Prawo rzymskie a współczesność (T. Giaro i F. Longchamps de Bérier) we wstępie do wydania z 2013 r. piszą, że ,z końcem lat sześćdziesiątych nasz mistrz przechodził w tej dziedzinie [t. j. papirologii prawniczej] swego rodzaju kryzys świadomości [podkreślenie W.W.]. Papirologia oznaczała bowiem konieczność zanurzenia prawa rzymskiego w realiach starożytnego Egiptu i zbliżenie się raczej do typu badań na Wydziale Historii, dokąd zresztą kierowany przez R. Taubenshlaga Zakład Papirologii i Praw Antycznych został przeniesiony z Wydziału Prawa”" Trudno tu chyba mówić o „kryzysie świadomości” Henryka Kupiszewskiego, lecz raczej o zauroczeniu Maxem Kaserem i jego stosunkiem do badań nad prawem rzymskim. Podobnie jak młody Kupiszewski na pierwszym roku studiów w Krakowie chłonął prawo rzymskie w wydaniu Wacława Osuchowskiego, tak dzięki pracy naukowej w szkole Maxa Kasera zobaczył rzeczywiste wartości prawa rzymskiego dla współczesności.

Po śmierci Rafała Taubenschlaga Henryk Kupiszewski tak samo, jak Instytut Papirologii i jego bogata biblioteka, przeszedł na Wydział Prawa U.W., gdzie Katedrą Prawa Rzymskiego kierował prof. Edward Gintowt. Tu też przeprowadził Henryk Kupiszewski przewód habilitacyjny na podstawie pracy dotyczącej zaręczyn w archaicznym i klasycznym prawie rzymskim ${ }^{12}$, zakończony w 1964 r. na Wydziale Prawa Uniwersytetu Warszawskiego. Tu przeszedł też dalsze etapy naukowej kariery.

11 T. Giaro i F. Longchamps de Bérier, we wstępie do: H. Kupiszewski, Prawo rzymskie a współczesność, wyd. 2, przejrzeli i wstępem opatrzyli T. Giaro i F. Longchamps de Bérier, Kraków 2013, s. 8. Wydawcy, nie wiadomo, dlaczego, pominęli tak istotny dla czytelnika „Indeks źródeł” oraz „Indeks rzeczowy”, które znajdowały się w wydaniu z roku 1988, przygotowanym przez Henryka Kupiszewskiego. Przenieśli natomiast słusznie przypisy, z końca rozdziałów, na odpowiednie strony tekstu.

12 Por. H. Kupiszewski, Das Verlöbnis im altrömischen Recht, «ZSS» 77/1961, s. 125-159, IDEm, Studien zum Verlöbnis im klassischen römischen Recht, «ZSS» $84 / 1967$, s. $70-103$. 
W 1961 r. Edward Gintowt, który, oprócz pracy w Uniwersytecie Warszawskim, wykładał również prawo rzymskie na Akademii Teologii Katolickiej, z uwagi na zły stan zdrowia, przekazał (jeszcze przed habilitacją) swój wykład na Akademii Teologii Katolickiej Henrykowi Kupiszewskiemu, który w 1974 r. objął tam katedrę Prawa Rzymskiego. Wykład w Akademii Teologii Katolickiej na Wydziale Prawa Kanonicznego i uzyskaną tamże missio canonica, Henryk Kupiszewski traktował bardzo poważnie. Wykłady w Akademii Teologii Katolickiej traktował jako najwspanialszy moment swojej kariery dydaktycznej i naukowej ${ }^{13}$. Ten okres swojego życia naukowego Henryk Kupiszewki traktował jako niezmiernie ważny. Przyczynił się on do jego jeszcze większego zbliżenia do Kościoła Katolickiego ${ }^{14}$.

Zainteresowania naukowe Henryka w czasie jego pracy jako docenta, a następnie profesora Wydziału Prawa i Administracji UW dotyczyły głównie szeroko pojętego prawa rzymskiego. Interesowała go nie tylko historia wewnętrzna prawa rzymskiego (rzecz niezbędna w wykładzie uniwersyteckim dla studentów), lecz również jego związek ze stosunkami społecznymi, gospodarczymi, i politycznymi świata starożytnego oraz jego wpływ na świat współczesny.

W ostatnich latach życia naukowego Henryk Kupiszewski zainteresował się studiami dotyczącymi filozoficznych i logicznych podstaw prawa rzymskiego i jego wpływu na prawo współczesne. Opublikował liczne artykuły ${ }^{15}$, które następnie zostały zgrabnie zebrane w zbiorze zatytułowanym „Prawo rzymskie a współczesność”16. Odgrywało tu również swoistą rolę nasycenie prawa rzymskiego elementami sakralnymi. Zespolenie prawa boskiego (fas) i prawa ludzkiego (ius) w daw-

13 Por. J. ZABŁocki w nekrologu, opublikowanym w «Orbis Iuris Romani. Journal of Ancient Law Studies» 3/1997, s. 118: Il lavoro alla Facoltà di Diritto Canonica dell'Accademia di Teologia Cattolica di Varsavia il Professor Kupiszewski considerava sempre come uno dei più splendidi momenti della sua carriera didattica e scientifica.

14 Nie zapomnę, jak bardzo oburzony był Henryk Kupiszewski, gdy w wydanej przeze mnie w roku 1986 Encyklopedii prawa rzymskiego, znalazł słowo Kościół pisane z małej litery.

15 Por. M. ZABŁOCKA, op. cit.

16 H. Kupiszewski, Prawo rzymskie... . 
nym prawie rzymskim, odpowiadało ideom przekształceń ustrojowych u zarania III Rzeczypospolitej. Odpowiadało również wizji łączności prawa i norm etycznych. W książce Henryka Kupiszewskiego ten element humanizacji i uetycznienia prawa występuje wyraźnie. Autor, odnosząc się do badań takich autorów jak M. Kaser, F. Horak, M. Bretone, D. Nörr, pisze, że „Wszystkie one odchodzą od badań nad instytucjami, a mają za przedmiot powstawanie, formowanie się prawa w najszerszym tego słowa znaczeniu. Wśród tych zagadnień podejmowanych współcześnie ważne miejsce zajmuje określenie wartości etycznych prawa rzymskiego"17.

Książka ta - wydana na rok przed polskimi przemianami politycznymi i społecznymi w 1989 r. (składająca się z ośmiu rozdziałów ${ }^{18}$ ) wywołała duży oddźwięk w czasie ustrojowych przemian w Polsce. Trafiła idealnie w zainteresowania polskiego świata politycznego w okresie formowania III Rzeczypospolitej. Idee stoickie z dążeniem do globalizacji świata i sympatią między ludźmi - do których nawiązywał H. Kupiszewski - były życzliwie przyjmowane w okresie początków nowego pokomunistycznego ustroju.

Nic więc dziwnego, że w wypowiedziach polityków i parlamentarzystów pojawiała się często idea prawa sprawiedliwego, dobrego, opartego na prawie rzymskim będącego przejawem cywilizacji łacińskiej, przeciwstawiającej się globalizacji bizantyjskiej ${ }^{19}$. W dyskusjach sejmowych dotyczących miejsca Polski w Unii Europejskiej często pojawiało się - i to zarówno w ustach zwolenników, jak i przeciwników integracji europejskiej - spopularyzowane przez Henryka Ku-

17 H. KuPISZEwski, Prawo rzymskie..., s. 177.

18 Rozdziały tej książki: 1. Prawo rzymskie ongiś i dziś; 2. Od Bejrutu i Konstantynopola do Bolonii; 3. Prawo rzymskie a ustawodawstwo i nauka praca cywilnego na przełomie XIX i XX wieku; 4. 'Maximae iuris'; 5. 'Regulae iuris'; 6. 'Humanitas' a prawo rzymskie; 7. Od kodeksu-książki do kodeksu-zbioru przepisów prawnych; 8. Prawo rzymskie - źródło inspiracji wiecznie żywe; indeksy źródeł i rzeczowy.

19 Por W. WoŁodkiewicz, Europa i prawo rzymskie. Szkice z historii europejskiej kultury prawnej, Warszawa 2009, s. 123, 126. 
piszewskiego stwierdzenie, że „Europa jest syntezą filozofii greckiej, prawa rzymskiego i religii chrześcijańskiej”"20.

W ujęciu Henryka Kupiszewskiego prawo rzymskie to system dobry i szlachetny, który wraz z etyką powinien stać się ,środkiem obrony ludzi przed techniką, która nas postawiła nad brzegiem niebytu"21. Tak samo traktował też Henryk Kupiszewski prawo rzymskie, gdy w dniu 16 czerwca 1990 r. składał papieżowi Janowi Pawłowi II, w imieniu Rządu Rzeczypospolitej, listy uwierzytelniające. W swym przemówieniu, ogłoszonym w „Osservatore Romano”, nawiązywał do roli prawa rzymskiego w tworzeniu współczesnych porządków prawnych. Mówił: „Wśród różnych instrumentów, które nam je pozwolą wypełnić, znajduje się prawo. Wymaga ono szybkiego przekształcenia na takie, którego normy wypływają z praecepta etycznych. Właśnie oparcie przepisów na idei iustitia, aequitas, fides, benignitas spowoduje, że stanie się ono ars boni et aequi i zapewni suum cuique, że uzna za swoją naturalną, a fundamentalną zasadę: homo est et qui futurus i zapewni ochronę życia człowieka we wszystkich jego wymiarach duchowych i materialnych”. ... „Europę — mówił w powołanym przemówieniu — jako fenomen kulturalny formowała filozofia grecka. Formowało ją prawo rzymskie, które w postaci ius commune było podstawą porządków prawnych do ubiegłego stulecia. Przede wszystkim uformowało ją jednakże chrześcijaństwo. Ono właśnie dało Europie i światu system wartości najwyższych i uniwersalnych. Przystępując dziś do budowy jedności Europy w sensie politycznym i gospodarczym, chcemy ją właśnie oprzeć na tych wartościach, bo tylko one są w stanie zapewnić pomyślną przyszłość. Wspólne dla zachodu i wschodu kontynentu, da Roma a Terza Roma, staną się fundamentem, na którym zakwitnie przyjaźń i braterstwo ludów, narodów i państw ..."22.

W sposób niezmiernie żywy i krytyczny reagował Henryk Kupiszewski na przeczytane prace. Po pewnym czasie tematyka krytykowana zaczynała Go jednak pasjonować. Podkreślał ścisły związek

20 Ibidem, s. 124.

21 H. Kupiszewski, Prawo rzymskie..., s. 232

22 «Osservatore Romano» z dnia 17 lipca 1990 roku, s. 4. 
dydaktyki i badań naukowych. „Współcześnie jest nie do pomyślenia — pisał kilka miesięcy przed śmiercią, w referacie przedstawiającym meandry nauki i nauczania prawa rzymskiego w Europie i w Polsce - uprawianie nauki prawa rzymskiego bez dydaktyki. Odwrotna sytuacja, to jest dydaktyka bez badań naukowych, prowadzi do uwiądu przedmiotu. I nie jest to tylko moje zdanie, ale opinio communis uczonych wszystkich krajów"23.

Był Henryk Kupiszewski niestrudzonym orędownikiem i twórcą międzynarodowej wymiany naukowej. Kierowany przez niego, po śmierci Rafała Taubenschlaga, „Journal of Juristic Papyrology” jest znany w całym świecie. Kontakty międzynarodowe Henryka Kupiszewskiego były wielokierunkowe. Wspomnę tu jedynie o Jego najbardziej umiłowanym kraju, o Italii. Był znakomitym inicjatorem naukowych kontaktów międzynarodowych i to nie tylko Uniwersytetu Warszawskiego. Jego zasługą był rozwój współpracy naukowej z uniwersytetami i instytucjami naukowymi włoskimi (wspomnę tu jedynie o Accademia Nazionale dei Lincei, uniwersytetach w Rzymie, Padwie, Camerino, Neapolu). Można Mu zawdzięczać, że współpraca ta nie została nigdy przerwana, nawet w latach, gdy stały jej na przeszkodzie najrozmaitsze trudności.

Mimo rozlicznych obowiązków dyplomatycznych, w ostatnim okresie swego życia nie zaprzestał Henryk Kupiszewski umiłowanej pracy naukowej. Pamiętam nasze spotkanie w siedzibie rzymskiej Ambasady w początku pełnienia Jego misji. Na biurku, obok ważnych dokumentów państwowych (w tym przygotowywanego konkordatu Polski ze Stolicą Apostolską, którego był gorącym propagatorem) leżały książki z prawa rzymskiego. Na pytanie, czy ma czas pracować jeszcze naukowo, odpowiedział, że przychodzi do Ambasady bardzo

${ }^{23}$ Z referatu przygotowanego na Sesję Komisji Praw Antycznych przy Komitecie Nauk o Kulturze Antycznej PAN, w Zajączkowie w listopadzie 1993 roku. Autor złożony już nieuleczalną chorobą nie mógł wziąć osobiście udziału w Sesji. Prosił jednak o odczytanie tekstu. Włoskie thumaczenie tego referatu zostało opublikowane w zbiorze: Le droit Romain et le monde contemporain. Mélange à la memoire de Henryk Kupiszewski, sous la rédaction de W. WoŁodKIEWICZ et M. ZABŁockA, Varsovie 1996, s. $163-173$. 
wcześnie, aby móc choć trochę poczytać i popisać o prawie rzymskim. W czerwcu 1993 r. brał aktywny udział w pracach „Premio Internazionale Gérard Boulvert w Neapolu".

Gdy rozmawiałem z Henrykiem kilka tygodni przed śmiercią mówił, że pewno w wakacje będziemy się żegnać. Niestety, opuścił nas wcześniej, 3 kwietnia 1994 r., w dzień Święta Zmartwychwstania. Od tej przedwczesnej śmierci mija dziś 20 lat.

\section{HENRYK KUPISZEWSKI’s VISION OF ROMAN LAW}

\section{Summary}

This article is an extended version of the author's paper delivered at the International Conference held at the University of Warsaw to commemorate the twentieth anniversary of the death of Professor Henryk Kupiszewski. The author presents the biography and academic developments in the life of Kupiszewski, a student of Wacław Osuchowski, Rafał Taubenschlag, and Max Kaser. He then goes on to discuss Kupiszewski's main research interests. Starting with papyrology for the legal sciences, Kupiszewski moved on to research on the internal history of classical Roman law and finally to the study of the impact of Roman law on contemporary law and legal culture. The author also recalls Kupiszewski's work in international co-operation in scholarship and for the Polish diplomatic service as ambassador to the Vatican.

Słowa kluczowe: Henryk Kupiszewski; prawo rzymskie, międzynarodowa współpraca naukowa.

Keywords: Henryk Kupiszewski; Roman law, international academic cooperation. 